\title{
The first posterior fossa decompression for Chiari malformation: the contributions of Cornelis Joachimus van Houweninge Graftdijk and a review of the infancy of "Chiari decompression"
}

\author{
Martin M. Mortazavi • R. Shane Tubbs • \\ Todd C. Hankinson • Jeffrey A. Pugh • \\ Aaron A. Cohen-Gadol $\cdot$ W. Jerry Oakes
}

Published online: 6 April 2011

(C) Springer-Verlag 2011

\begin{abstract}
Over the past several decades, our understanding of the pathophysiology of hindbrain hernias has markedly increased. Additionally, with the advent of MRI, diagnosis of these entities is common. Although the history of the discovery of what are now known as the Chiari malformations is well known, publications regarding the historical surgical treatment of these is, to our knowledge, not extant. Many have attributed the first successful patient series to Gardner in the 1950s. However, and unknown to many, the first description of a hindbrain decompression was in 1930 by the Dutchman Cornelis Joachimus van Houweninge Graftdijk. This neurosurgeon also added to our understanding the pathophysiology of hindbrain herniation and its relationship to raised intracranial pressure. The present paper reviews the contributions of this early pioneer of neurosurgery.
\end{abstract}

Keywords History · Neurosurgery · Hindbrain hernia · Arnold-Chiari · Surgery

\footnotetext{
M. M. Mortazavi • R. S. Tubbs $(\bowtie) \cdot$ T. C. Hankinson •

W. J. Oakes

Section of Pediatric Neurosurgery, Children's Hospital, 1600 7th Avenue South ACC 400,

Birmingham, AL 35233, USA

e-mail: rstubbs@uab.edu

\section{J. A. Pugh}

Division of Neurosurgery, University of Alberta,

Edmonton, AB, Canada
}

\section{A. A. Cohen-Gadol}

Department of Neurosurgery, Clarian Neuroscience Institute, Indianapolis Neurosurgical Group and Indiana University, Indianapolis, IN, USA
The anomaly [Chiari malformation] may present itself as an unexpected clinical problem to be dealt with by the neurosurgeon.

Penfield Wilder

\section{Descriptions of the Chiari malformation}

In 1891, Dr. Hans Chiari, professor of pathological anatomy at the German University in Prague, using autopsy specimens, published (Deutsche Medizinische Wochenschrift) on what would later be termed the Chiari malformations $[4,14]$. However, Chiari was not the first to observe and report the type II malformations. In Observationes Medicae, written by the Dutch physician and anatomist Nicholas Tulp (1593-1674), reference is made to hindbrain herniation in a myelodysplastic individual. John Cleland (1835-1925) of Scotland reported a single myelodysplastic patient with hindbrain herniation and hydrocephalus in 1883 [14]. In 1894, Julius Arnold (1835-1915), professor of anatomy at Heidelberg, described a single myelodysplastic patient with hindbrain herniation and no hydrocephalus [4]. Following these discoveries and many years later, in 1935, Russell and Donald [12] at the London Hospital described 10 additional pathological specimens of Chiari malformations.

\section{Surgical history of the Chiari malformations}

In 1938, Penfield and Coburn [11] in Montreal reported a 29-year-old woman with loss of hearing and weakness on the right side of the face. Her history included amputation 
for a thoracic "spina bifida" in infancy. On physical examination, she was noted to have nystagmus, absence of the right corneal reflex, truncal ataxia, and decreased reflexes. The patient underwent posterior fossa exploration with the authors not considering hindbrain herniation in their differential. Penfield and Coburn later stated that:

In retrospect it seems that we should have suspected the Arnold-Chiari malformation. Instead, a suboccipital craniotomy was carried out, with a tentative diagnosis of a tumor of the acoustic nerve bilaterally [11].

The patient of Penfield and Coburn never regained consciousness and died 2 months later. At autopsy, the authors identified a Chiari II malformation and hydrocephalus. These authors suggested that in the future, the cerebellar tonsils be left intact and that the posterior margin of the foramen magnum be removed with the posterior elements of C1 and C2 [11]. Also in 1938, McConnell and Parker [8] published their results of posterior fossa decompression for Chiari I malformation in five patients. Two of these patients had successful outcomes. In 1945, Bucy and Lichtenstein [2] reported successful decompression for a Chiari I malformation of a 40-year-old woman without hydrocephalus, and in 1948, Chorobski and Stepien [3] operated a woman with life-altering, valsalva-induced headache and Chiari I malformation that had full resolution of her symptoms. Most remembered for his direct approach to the hindbrain was Gardner. In 1957, he and Goodall [6] reported their efforts at surgically addressing syringomyelia by decompressing the hindbrain and sealing off the hypothetical communication between the syrinx and fourth ventricle in 17 patients. They reported improvement in 13, decline in 3 , and death in 1 . In their series, some patients had improvement of preoperative symptoms. The publication of Garner and Goodall appears to have resulted in the widespread adoption of posterior fossa decompression for hindbrain herniation with larger reports following over the next few decades $[1,5,7,9,10,13]$.

\section{Contributions of Van Houweninge Graftdijk}

Not known to many is that 8 years prior to the publication of Penfield and Coburn, Cornelis Joachimus van Houweninge Graftdijk (Fig. 1) operated a patient, in 1930, with myelomeningocele and ventriculogram-proven hindbrain herniation who had rapid head growth. This contribution was published in his thesis for a Doctorate of Medicine entitled Over Hydrocephalus (about hydrocephalus, Fig. 2) [15]. With this endeavor, he attempted to relieve CSF obstruction at the craniocervical junction by redundant cerebellar tissue. Although his patient died, this
Fig. 1 Photograph of Van Houweninge Graftdijk (1888-1956)

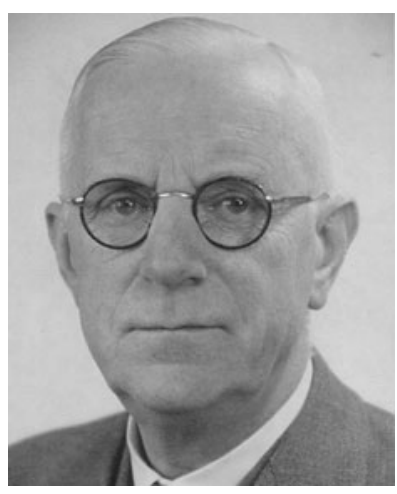

report marks the first known attempt at surgical correction of a hindbrain herniation. Van Houweninge Graftdijk stated:

I decided to try widening the space through which the brain had herniated in order to allow for better flow of CSF [15].

The idea that displacement of the foramina of the fourth ventricle into the upper end of the spinal canal might precipitate hydrocephalus, and that the whole of the anomaly might act as a valve, was first expressed by Van Houweninge Graftdijk in 1932 [15]. For this case, part of the occipital bone and posterior elements of the first two vertebrae were removed. The patient developed fever on postoperative day 2 , and 84 days after the operation, the bladder was perforated so that on day 98 postoperative, the patient died.

Van Houweninge Graftdijk also presented evidence that fluid could flow more readily from the spine to the head than vice versa [17]. It was in children with spina bifida that he concluded that the pressure within the meningocoele was lower than the pressure within the cranium [18]. Conversely, Russell and Donald [12] commented on Van Houweninge Graftdijk's theory but hypothesized that hindbrain hernias did not cause hydrocephalus in these patients. Interestingly, in 1935, these authors stated:

If hydrocephalus, either congenital or postoperative, were due to such a malformation, then air injected by the lumbar route would collect in the ventricles and not in the sulci upon the cerebral convexities. Such a result would be not only of academic interest but of clinical importance. It would point to the desirability of decompressing the spinal cord at the foramen magnum to facilitate the circulation of fluid in the leptomeningeal spaces. Such an operation has not yet been carried out [12]. These authors, in a foot note, state that while there above mentioned paper was in press, 
Fig. 2 Title page from Van

Houweninge Graftdijk's Over

hydrocephalus

\title{
OVER HYDROCEPHALUS
}

\author{
PROEFSCHRIFT TER VERKRIJGING VAN DEN \\ GRAAD VAN DOCTOR IN DE GENEESKUNDE \\ AAN DE RIJKSUNIVERSITEIT TE LEIDEN, \\ OP GEZAG VAN DEN RECTOR-MAGNIFICUS \\ DR. J. J. B L A N K S M A, HOOGLEERAAR IN DE \\ FACULTEIT DER WIS- EN NATUURKUNDE, \\ VOOR DE FACULTEIT DER GENEESKUNDE TE \\ VERDEDIGEN OP DINSDAG 21 JUNI 1932 , \\ DES NAMIDDAGS TE 4 UUR, \\ DOOR \\ Cornelis Joachimus van Houweninge Graftdijk
Griboren twe giessendan.
}

N. V. BOEK- EN STEENDRUKKERLJ IDUARD IJDO - LEIDEN.

that their attention was drawn to the thesis of Van Houweninge Graftdijk. Van Houweninge Graftdijk also surmised, based on experimental evidence, that cerebrospinal fluid can readily escape in an upward direction from the vertebral canal into the ventricles or cerebral meningeal spaces but has difficulty in passing from the ventricles down into the vertebral canal. To address such issues surgically, he resected redundant cerebellar tissue and or bone over the posterior surface of the malformation as previously mentioned $[12,15]$. Van Houweninge Graftdijk also postulated that caudal traction theory by the myelomeningocele is responsible for "pulling" the hindbrain caudally thus resulting in a Chiari II malformation [18].

\section{Life}

Cornelis Joachimus van Houweninge Graftdijk was born September 25, 1888 in Giessendam, Holland, the son of Aris Graftdijk and Gerrigje Johanna van Houweninge who 
Fig. 3 Van Houweninge Graftdijk and his operating room staff

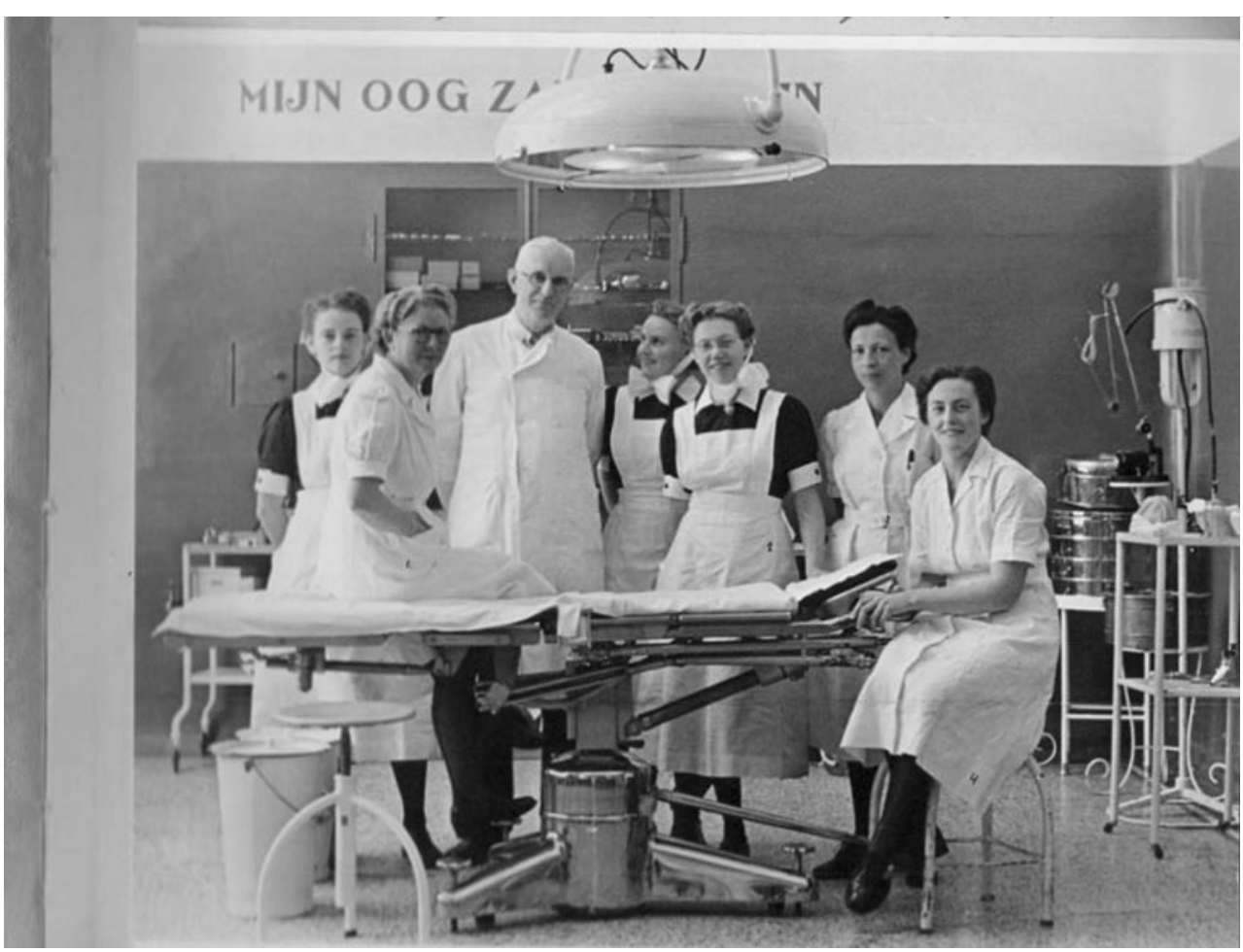

had three other children Adriaan, Wilhelmina, and Louisa Maria Frederika.

Cornelis' father was a family doctor in Giessendam and his brother Adriaan died relatively young as the result of

hydrocephalus. Due to his brother's illness, his siblings were sent to boarding school. Although his brother and sisters were given the family surname Graftdijk, Cornelis was given the name Van Houweninge Graftdijk as his

Fig. 4 Van Houweninge

Graftdijk operating

(background)

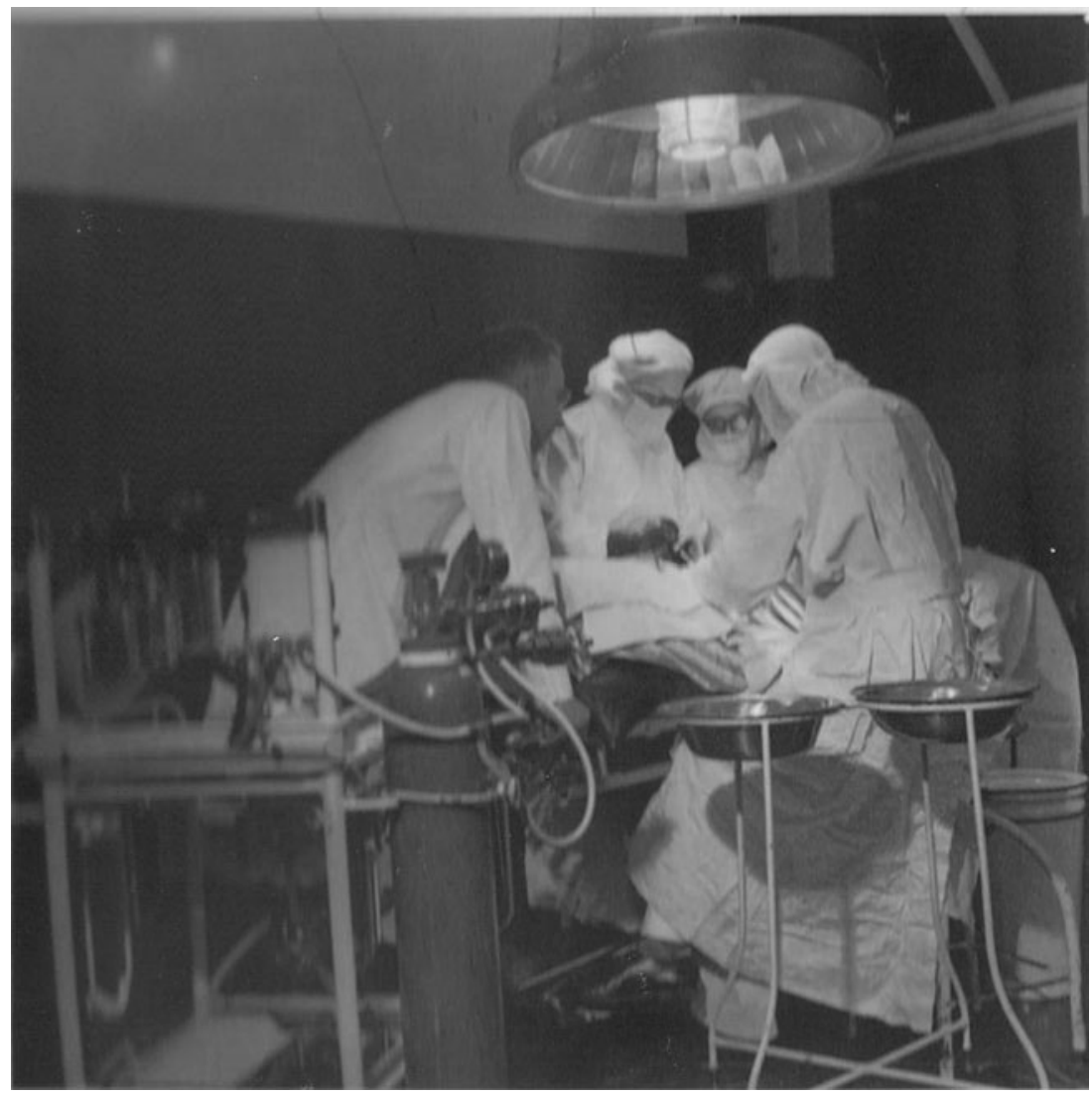


parents did not want this surname to die out. Cornelis graduated from the University of Leiden. He became a physician in 1913 and following the advice of his teacher Professor Korteweg, became a ship doctor so that he could gain some "practical knowledge." In 1914, he returned to the Department of Surgery at Leiden University Hospital and soon after, Professor Korteweg died. Van Houweninge Graftdijk was soon introduced to Prof. Zaaijer who introduced him to surgery. He studied with Prof. Zaaijer for 5 years then began his own practice as a surgeon in Leiden at the hospital Diaconessenhuis (Figs. 3 and 4). He maintained his affiliation with Prof. Zaaijer at the University Hospital in Leiden and in addition to practicing general surgery, treated pediatric patients with hydrocephalus. This interest probably arose from his concern over his older brother who had hydrocephalus. Van Houweninge Graftdijk trained doctors in surgery and for many years, was "chef de clinique" of the Department of Surgery at University Hospital.

On July 3, 1923, Van Houweninge Graftdijk married Elsje Coenen, a banker's daughter and eventually, had two sons. Nine years later, at the urging of Prof. Zaaijer, van Houweninge Graftdijk wrote his dissertation [15] on hydrocephalus; and on June 21, 1932, he obtained his doctor's degree cum laude. Soon after, Prof. Zaaijer left the university and was replaced by Prof. Suermondt who had no interest in hydrocephalus. It is not clear why Van Houweninge Graftdijk did not succeed Prof. Zaaijer, but as a result of this, he left University Hospital and was not able to continue working on hydrocephalus which he very much regretted. He continued to practice as a surgeon at the hospital Diaconnessenhuis but was offered professorships in Groningen, (Holland) and in Indonesia.

Interestingly, in 1938, he removed the appendix from his youngest son Willem and later, prophylactically removed the appendix of his eldest son prior to a long journey at sea. Van Houweninge Graftdijk said: "it is safer that it is out now than to wait until you are at sea." Additionally, in 1940, Van Houweninge Graftdijk operated his wife to remove a kidney filled with stones. He said: "I will do it myself. If it is easy I can do it myself and if it is difficult I want to do it myself." His friend and fellow surgeon Kingma Boltjes attended the surgery in the event that Van Houweninge Graftdijk might become "emotional."

Van Houweninge Graftdijk's hobbies included rowing and reading books on history, philosophy, politics, and medicine. He was a member of the rotary club in Leiden and treasurer for the Archivum Chirurgicum and chairman of the Dutch Association of Surgery in the year this association celebrated its 50th anniversary. This was an honor as, generally, only professors became chairman of this association. In 1940, he wrote a book "Heelkunde voor Den Medicus Practicus" [16], a textbook of surgery for family doctors. In 1956, Van Houweninge Graftdijk transferred his practice to Dr. H. Muller, a surgeon in Leiden, who was affiliated with the Department of Surgery at the University Hospital. Soon after this transfer, he died on September 28. He is remembered as a hard-working physician who was very sympathetic to his patients. For example, his two sons remembered their nearly empty toy box as their father took their toys away to give to the children at the hospital and explained to his sons "you have enough toys to play with, these poor children have nothing at all" (Willem Aris van Houweninge Graftdijk, personal communication).

\section{Conclusions}

The evolution of surgery for hindbrain herniation is indebted to pioneers such as Van Houweninge Graftdijk for his significant contributions to our understanding and treatment of these embryological derailments (Fig. 5).

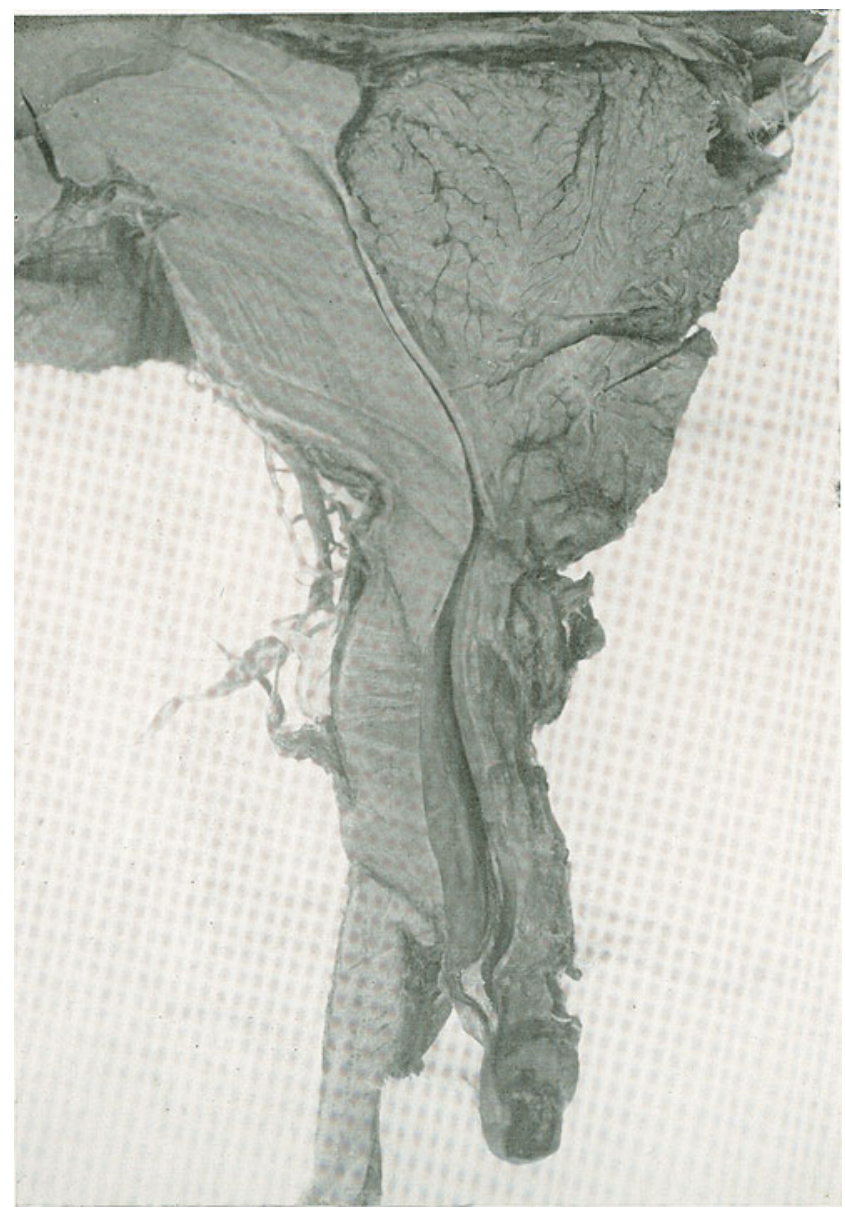

Fig. 5 Pathological specimen from a patient of Van Houweninge Graftdijk's demonstrating the Chiari II malformation 
Acknowledgment The authors are grateful to Evelien van Houweninge Graftdijk and Willem Aris van Houweninge Graftdijk, the grandaughter and son of Van Houweninge Graftdijk for providing photographs and additional and significant information regarding Van Houweninge Graftdijk's life.

\section{References}

1. Adams RD, Schatzki R, Scoville WB (1941) The Arnold-Chiari malformation. Diagnosis, demonstration by intraspinal Lipiodol and successful surgical treatment. N Engl J Med 225:125131

2. Bucy PC, Lichtenstein BW (1945) Arnold-Chiari deformity in an adult without obvious cause. J Neurosurg 2:245-250

3. Chorobski J, Stepien L (1948) On the syndrome of Arnold-Chiari. Report of a case. J Neurosurg 5:495-500

4. de Lotbinière ACJ (1997) In: Anson JA, Benzel EC, Awad IA (eds) Historical considerations in syringomyelia and the Chiari malformations. American Association of Neurological Surgeons, Chicago, pp 1-26

5. D'errico A (1939) The surgical treatment of hydrocephalus associated with spina bifida. Yale J Biol Med 11:425-430

6. Gardner WJ, Goodall RJ (1950) The surgical treatment of Arnold-Chiari malformation in adults: an explanation of its mechanism and importance of encephalography in diagnosis. $\mathrm{J}$ Neurosurg 7:199-206
7. List CF (1941) Neurologic syndromes accompanying developmental anomalies of occipital bone, atlas and axis. Arch Neurol Psychiatry 45:577-616

8. McConnell AA, Parker HL (1938) A deformity of the hind-brain associated with internal hydrocephalus. Its relation to the ArnoldChiari malformation. Brain 61:415-429

9. Ogryzlo MA (1942) The Arnold-Chiari malformation. Arch Neurol Psychiatry 48:30-46

10. Paul KS, Lye RH, Strang FA, Dutton J (1983) Arnold-Chiari malformation. J Neurosurg 58:183-187

11. Penfield W, Coburn DF (1938) Arnold-Chiari malformation and its operative treatment. Arch Neurol Psychiatry 40:328-336

12. Russell DS, Donald C (1935) The mechanism of internal hydrocephalus in spina bifida. Brain 58:203-215

13. Saez R, Onofrio BM, Yanagihara T (1976) Experience with Arnold-Chiari malformation, 1960-1970. J Neurosurg 45:416-422

14. Tubbs RS, Oakes WJ (2004) Chiari malformations. In: Winn HR (ed) Youmans neurological surgery, 5th edn. Saunders, Philadelphia, pp 3347-3361

15. Van Houweninge Graftdijk CJ (1932) Over hydrocephalus. Eduard Ijdo, Leiden

16. Van Houweninge Graftdijk CJ (1940) Heelkunde voor Den Medicus Practicus. HE Stenfert's Kroese, Leiden

17. Williams B (1971) Further thoughts on the valvular action of the Arnold-Chiari malformation. Dev Med Child Neurol 13:105-112

18. Williams B (1975) Cerebrospinal fluid pressure-gradients in spina bifida cystic, with special reference to the Arnold-Chiari malformation and aqueductal stenosis. Dev Med Child Neurol 17:138-150 